\title{
Alterity and Autochthony: Austronesian Cosmographies of the Marvellous ${ }^{1}$
}

\author{
Marshall Sahlins
}

Raymond Firth's Tikopia corpus is a treasure for all time. 'A treasure for all time' was Thucydides's modest assessment of his own History of the Peloponnesian War, no doubt intended as an invidious contrast to Herodotus, since it followed from the observation that he was not one to pander to a credulous public by relating fanciful tales of the marvellous. Indeed, Thucydides's invocations of a universal, interestdriven rationality based on supposed natural desires of power and gainof the kind that led to the spectacularly irrational debacle of the Sicilian campaign-have made him the darling of contemporary IR realists. All the same, the ethnographically-informed history of Herodotus, rich in its accounts of local legends and unusual customs, turned out to be the real intellectual gold. And in the same way as Herodotus's sustained excursus on the marvellous of the peoples involved in the Greco-Persian

1 Marshall Sahlins originally delivered this text as the Raymond Firth Lecture in Verona, at the 2008 European Society for Oceanists (ESfO) conference. We subsequently translated it into Italian for publication in La Ricerca Folklorica 63 (2011). In agreement with the author and the editors of $H A U$, the paper was first published in English in volume 2(2) 2012 of the journal, with the understanding that it would also be included in this volume. 
Wars, Raymond Firth's incredibly rich ethnography will be an enduring source of anthropological reflections on the cultural ordering of practice and history.

Here I proffer an example of Firth's legacy by taking up certain anomalies that he repeatedly observed in the Tikopian politics of autochthony and alterity. They offer insight into the phenomenon of stranger-kingship so widely distributed among Austronesian peoples and others the world over. Beyond that, Firth's ethnography of alterity opens the way to an anthropological appreciation of the politically marvellous, such as the descent of certain Malay sultans from Alexander the Great or the selfidentification of Polynesian chiefs with British royalty. For all the great value the Tikopians attached to autochthony of lineage, they were literally dying to participate in the wonders and powers of overseas lands'strolling around the sky', they called it—even as most gave no credence to the claim of the paramount Ariki Kafika that his original ancestors sprang from the Tikopian earth (Firth 1961: 53ff). In the opinion of most, the ruling chiefs came from lands in the foreign skies.

One of the differences between historians and anthropologists, most of them anyhow, is that the former are inclined to debunk such narratives in their pursuit of historical fact, while for anthropologists the issue is how, as cultural facts, they truly make history. For anthropologists the credence given to the seemingly marvellous opens questions of the distinct cultural logic these narratives entail and their efficacy as significant conditions of world order and practical action. The historians want to know 'what actually happened', the anthropologists, rather, what it meant to the people concerned-what it is that happened-from which actually follows the course of events.

\section{Alterity and autochthony in Tikopia}

For Firth, the striking 'anomaly' in the narratives of chiefly legitimacy was that, despite a near-obsessional concern for priority and indigeneity of lineage, and more particularly for autochthony, neither the ruling Kafika people nor any other ariki lineage had an indisputable claim to such status. A bare table of the relation between the rank of major lineages and the antiquity of their appearance in Tikopia was enough to show there was 'no close coincidence' between these attributes (Firth 1961: 178). On the other hand, several of the leading matapure, or ritual elders, although 
inferior in rank to ariki, could claim derivation from autochthonous peoples, such as the Nga Faea; or else, as in the case of one elder of Kafika (Pa Porima), his ancestor was senior and his god older than the chief's own ancients. Since, as Firth reported, the 'immense importance' of lineage priority is that it gives title to land, while at the same time the seniority of their ancestors gave the ritual elders certain ceremonial privileges, the relations of native elders to immigrant chiefs is much like that of 'owners' to rulers in many Austronesian stranger-kingships (Firth 1970: 55-57; 1967: 62ff; cf. Sahlins 2008). Recall the classic case of the ruling Tabalu subclan of the Trobriands, whose immigrant status in many villages Malinowski likewise found 'anomalous' in light of the privilege otherwise accorded to local, earth-born origins (1948: 94). (The 'anomalies' of alterity and autochthony are piling up: we are approaching a Kuhnian moment of paradigm shift, to which I hope to give further impetus here.)

Actually, the claim of the Ariki Kafika family was that they were ancestral strangers, the descendants of immigrant heroes who were human forms of the Pu Ma twins, autochthonous gods who had left Tikopia long before. The gods went away and came back as humans (like Captain Cook at Hawai $i$, for example). The Kafika ruling house would thus have it both ways, adding the values of the transcendental to the legitimacy of the local-had they been believed. However, even the so-called 'Sacred Tale' of Tikopia betrayed them. For it told that when the native $\mathrm{Pu} \mathrm{Ma}$ gods returned as men to Tikopia—when they 'came hither from foreign skies'-it was not as older and younger brother but as mother's brother and sister's son; and while the Kafika chief claimed descent from the latter, the sacred nephew, in this strictly patrilineal society it would leave him with unspecified lineage origins-he would still be a stranger. Indeed the mother's brother cum older brother of the original Pu Ma twins was rather the ancestor of a principal ritual-elder line. Here is the Tikopian version of the Austronesian relation between indigenous native elders and parvenu kings, with the transfer of sovereignty to the latter marked by a union of the original stranger with a daughter of the former.

In any event, the general body of the people knew the Kafika chiefs as canoe-borne immigrants rather than earth-born Tikopia, the principal matter in contention being whether they came from Pukapuka, Somosomo, or, more vaguely, Fiji. (The tradition of Somosomo origins, incidentally, strengthens the case for a settlement from the Fijian island of Cikobia, off Vanua Levu, as Somosomo in Taveuni was the ruling town of the Cakaudrove confederacy, the dominant polity in that area at least since 
the eighteenth century.) In the matter of chiefly origins, however, Tikopia shared more with Fiji than a few place names. Recall A.M. Hocart's report of the Lau man's observation that the ruling chiefs 'came from overseas; it is so in all countries of Fiji' (Hocart 1929: 27). Just so, the son of a former Ariki Kafika told Firth that whereas the traditional autochthonous peoples of Tikopia, the Nga Faea and Nga Ravenga, 'have their roots in the earth; we came here, we voyaged from overseas' (1961: 59).

Not that their immigrant origins had to be a slur on the status of Tikopian chiefs or a detriment to their authority. Only that, as we have seen, it put them on the transcendental side of the dual system of values, the opposition of foreign chiefs from the sky or sea and native people of the earth, that orders so many Austronesian polities. If Tikopians were almost obsessively concerned with autochthony, they were equally interested in entering into relations with the vital forces, beings and things in the celestial realms beyond the horizon. For as Firth observed, the European presence greatly expanded this cosmography of the marvellous, providing unparalleled opportunities for enhancing local authority by acquiring external agency.

In the few generations before Firth's 1929 fieldwork, well over 100 men undertook overseas voyages - the 1929 population was 1298-including one period when fleets of canoes set off in 'almost a frenzy ... and if they were not scattered by storms and lost, no sooner did their captains return to Tikopia than they set forth again' (ibid.: 152). More than half died at sea. And in another spate of 30 voyages after 1929, about 80 men were lost. Firth cites a stanza from a well-known song:

We here, great is the greed of our eyes

For valuables from abroad

Which come with disaster (1957: 36).

Were not the dangers of the foreign a sign of its powers? And would not overcoming these risks endow value and prestige on the successful voyagers? Probably this was what Firth meant in speaking of the spirit of adventure animating these men, and the meaning also of the little ritual attending their return (1957: 18-21). The successful voyager was smeared with turmeric by his mother's brother as 'a mark of distinction', and the family of the mother's brother carried a basket of food to him. The ceremonial welcome is structurally isomorphic with the advent of the Ariki Kafika's human ancestor from abroad in the Sacred Tale of Tikopian chieftainship. According to the Sacred Tale, the rule and the resources of the island-political analogues of the mark of distinction and 
the basket of food in the welcome ritual—were accorded the immigrant sister's son or 'sacred child' (tama tapu), the avatar of the younger of the foundational twin gods $(\mathrm{Pu} \mathrm{Ma})$. The turmeric makes the connection between the structural registers of kingship and kinship. Produced in a highly ritualised manner and stored as an object of great value, turmeric was the perfume of the great culture hero and Kafika ancestor, the Atua i Kafika. Turmeric attracted the sacred hero and, as applied to the principal persons and objects of important ceremonies, in effect consecrated them (Firth 1950, 1957).

The social value that Tikopia men acquired from voyages in the transcendental world was expressed in the tales they told, in the objects they bought back, even in the talismanic virtues of English phrases they had learned. These powerful words might be solicited from them with gifts by stay-at-homes; or else, the returning voyagers kept their English to themselves for the advantages it gave them in dealing with European visitors. Most tellingly, successful voyagers came back with foreign names for themselves and their houses. Consider that, apart from members of the immediate family, Tikopians know each other by the names of their dwellings: as 'Pa' (husband) and 'Nau' (wife) prefixed to the house-name. So if the house was known as Niukaso or Melipani, the inhabitants were 'the Newcastles' or 'the Melbournes'. Moreover, other relatives might solicit or inherit such foreign names from their voyaging kinfolk. It follows that alterity is a widespread condition of Tikopians' native identity.

The complement of the acquisition of status from abroad is the power that important foreign visitors were thought to exercise, for better or for worse. Firth noted that although in the island the title of ariki was exclusively used for the four clan chiefs (and in certain ritual formulas, for the gods), it was liberally accorded to distinguished members of other societies, particularly Europeans such as ship captains, senior government officials, the Bishop of Melanesia, and their like (1970: 39-40). Some of these outsiders might even be the subjects of avoidance taboos. Firth considered such practices as courtesies for the most part, although the question remains why the foreigners merited such deference; and more significantly, why they were specifically considered political figures, sometimes as the rivals of Tikopian ariki; and still more significantly, why some at least were attributed divine powers capable of bringing down natural disasters on the local people-and were inclined to do so. Regarding native Christian mission teachers (from other islands), it was held by prominent converts and 'heathens' alike that the teachers' object was 'to depreciate the status of chiefs' by taking away their rights to first 
fruits and other offerings. 'A general opinion was that the mission teachers, especially their leader, from another island, wish to exalt themselves at the expense of traditional authority' (1957: 46). Most notable were the powers of a former Bishop of Melanesia who resigned from his position for reasons of ill health. Although he had been generous to the Tikopians, they aver that on his departure he cursed the islands of his charge, causing a tidal wave from which Tikopia suffered in common with other places. He also sent grubs that devoured the taro (ibid.: 35).

The would-be good Bishop was hardly the first foreign person to be credited by Malayo-Polynesian people with divine powers akin to those of indigenous gods, or even the status of one of them now returned. In a seminal article, Ward Goodenough made the case that the famous Micronesian homeland Kachaw (Katau, Achau, etc.) referred to a spirit land in the sky, which helps explain why the Trukese always described the beings who came from there as énúuyaramas (i.e. spirits that can take fully human form). Besides Truk, the Sandeleur rulers of Nan Madol in Ponape claimed Kachaw origins, as did the dynasty that replaced them; while Belau and even atolls in the Carolines and Marshalls knew similar distinctions between immigrant rulers from the spirit world and the subordinate indigenous peoples. Goodenough (1986: 559) suggests that this can be a structure without an actual event, without an historical migration, insofar as local people 'who wish to bolster their political power with magical power' will claim ancestry from the transcendent spiritual realm. On the other hand, in certain real-historical metaphors of such mythical realities, 'Europeans, on their first arrival at Pacific islands were often greeted as if they were from the spirit world' (ibid.). By their own folkloric conceits, the Europeans attributed this status to their superior technology and firepower, but as Goodenough notes, in the islanders' 'viewpoint, they were simply the latest in a long succession of arrivals from the spirit world' (ibid.). Standing Marx on his head-hence back to Hegel right side up-by the islanders' lights, superior technology would be a function of the outsider's divinity rather than the other way around. If the Trukese assigned marvellous powers to their early European visitors, it was no more than they accorded the Master of Kachaw (Sowerkachaw), spirit-ancestor of their ruling chiefs, who made several trips to Truk by sea and air, riding a frigate bird, a banana, a scorpion fish and a whale, to mark his claim to the islands by names and deeds. ${ }^{2}$

2 On stranger-kings and stranger-chiefs of Micronesia see, among others: Parmentier (1987); Hanlon (1988); Bernart (1977); Petersen (1990); Lingenfelter (1975). 


\section{On stranger-kings in general ${ }^{3}$}

Stranger-kings or stranger-chiefs ruled indigenous peoples throughout much of the Austronesian world, from the Malay Peninsula to Hawai i. James Fox (1995a, 1995b, 2006) has made a careful analysis of the variant forms of these dualistic polities in Timor, Roti, Palembang (Sumatra), Gayo, Fiji, Bali and the Trobriands (cf. van Wouden 1968). In addition to the classic ethnographies of Firth, Malinowski, Goodenough and Hocart, Jukka Siikala has studied the like in the Cook Islands, Engseng Ho in Malaya, Janet Hoskins in Sumba, Glenn Petersen in Ponape, John Bowen in Gayo (Sumatra), Schulte Nordholt in Atoni (Timor), Josselin de Jong in Negri Sembilan (Malaya), Danilyn Rutherford in Biak, Thomas Gibson in South Sulawesi, R.H. Barnes in Lembata (Lesser Sundas), and Catarina Krizancic in the Society Islands, among others; while historians such as Anthony Reid, Jeyamalar Kathirithamby-Wells, Leonard Andaya, B. Schrieke, J.H. Walker, and O.W. Wolters have documented such polities in various Indonesian locations. I will not rehearse these findings in detail here. (Besides, I left out a lot of people.) Rather, I call attention to the larger planetary distribution of stranger-kingships in premodern societies, with a view toward a general description of their constitution and some reflections on the dynamics of their formation. ${ }^{4}$

If I called this description 'ideal-typical', would I be exonerated from the crime of essentialising? In any case, to generalise, if at some risk: by their dynastic origins, as rehearsed in ongoing traditions and enacted in royal rituals, the rulers of a remarkable number of societies around the world have been strangers to the places and peoples they rule. East, South and Southeast Asia have been breeding grounds of such outsider-kings from early times: not only in major centres such as the Cambodian kingdoms of Brahmin ancestry, the Ayudhya dynasty in Siam founded by a Chinese merchant prince, or the Lanka realm established by the princely descendant of a lion from India; but also in adjacent lowlands such as those occupied by Shan, Yi, or Malay principalities; and into the more peripheral areas

\footnotetext{
3 Parts of this section of the essay are rehearsed from an earlier article (Sahlins 2008) - the documentation of which leaves something to be desired. A fuller treatment of stranger-kingship is in preparation in book form: provisional title, The Stranger-King; or, the Powers of Otherness.

4 Aside from works previously cited, those noted in this paragraph are: Siikala $(1990 ; 1991 ; 1996)$; Ho (1999; 2002); Hoskins (1993); Schulte Nordholt (1971); Josselin de Jong (1975); Rutherford (2002); Gibson (2005); Barnes (1974); Krizancic (2006); Reid (1994; 2008); Kathirithamby-Wells (2006); L. Andaya (1975; cf. 2006); Schrieke (1957); Walker (2002); Wolters (1970; 1986). On Fijian analogues, see Sahlins (1981a; 2004).
} 
where hill peoples more or less willingly acknowledge the authority of lowland rulers, and their own leaders are known to have 'become Shan', Burmese, or Chinese in genealogy, attire and other attributes. ${ }^{5}$

Elsewhere I have noted similar structures among the Indo-European ancients (Sahlins 1981a, 2004). The early kings of the Peloponnesus down to Agamemnon and the Heraclid rulers of Sparta were Zeusdescended strangers. Aeneas was from Troy; while Romulus, warriorprince of Alba, founded Rome-by killing his brother and subsuming the indigenous Sabines through the slaughter of their men and marriage with their women. Sir James Frazer provided an early description of the phenomenon in the Indo-European family:

Thus it would seem that among some Aryan peoples, at a certain stage of their social evolution, it has been customary to regard women and not men as the channels in which royal blood flows, and to bestow the kingdom in each successive generation on a man of another family, and often of another country, who marries one of the princesses and reigns over his wife's people. A common type of popular tale which relates how an adventurer, coming to a strange land, wins the hand of the king's daughter and half or the whole of the kingdom, may well be the reminiscence of a real custom (Frazer 2006: 86; cf. Preaux 1962).

In something like the abduction of the Sabine women or the draconian usurpations of native rulers in the Peloponnesus, Africa too has been the site of conflictual-cum-contractual syntheses of indigenous 'owners' of the land and stranger-rulers of different ethnic origins, violent dispositions, and cosmic powers. Referring broadly to West and Central Africa, Luc de Heusch writes: 'Everything happens as if the very structure of a lineagebased society is not capable of engendering dialectical development on the political plane without the intervention of a new political structure. The sovereignty, the magical source of power, always comes from elsewhere, from a claimed original place, exterior to society' (1982a: 26).

5 See especially: Leach (1954); Strathern (2009); Li (2001); Lehman (1963); Horstmann and Wadley (2006); Turton (2000); Kasetsiri (1976); Robinne and Sadan (2007); Glahn (1987); Sprenger (2006); Fiskesjö (1999); Taylor (1983, 1999); Wyatt (1984); Backus (1981); Giersch (2006); Took (2005); Wang (1981). 
Well-known examples include Alur, Benin, Shilluk, Nupe, Mossi, Kongo, Luba, Lunda, Ruwanda, Nyoro, Burgo — not to mention the many lesser kingdoms and chiefdoms that are effectively satellites of the greater ones. ${ }^{6}$

The major American empires of the Aztecs and Inkas were ruled by immigrant strangers. Likewise, 'the arrival of strangers' initiated the Mayan dynasties of Tikal and Copan, according to the classic-period inscriptions, and similar kingly origins were known in post-classic cities of the Quiche, Mayapan and others. ${ }^{7}$

A common permutation-found in Japan, Korea, Natchez, Tongainvolves kings who originally came from the heavens, always a good address for persons of royal pretensions. Still another variant is the return of the ancestral stranger, such as we saw in Tikopia, where the dominant newcomers (sometimes) allege their descent from primordial local ancestors. Such is also the derivation of certain East African rulers and of many colonising Whitemen the world over, who were initially conceived by the indigenous people as long-lost brothers of their own legendary progenitors - if they were not the embodiments of their original gods.

Still generalising (and risking): in these stranger-kingdoms, two forms of authority and legitimacy coexist in a state of mutual dependence and reciprocal incorporation. The native people and the foreign rulers claim precedence on different grounds. For the underlying people, it is the founder principle, the right of first occupancy, or in the maximal case, the claim of autochthony. In many Austronesian as well as African societies the native people are the 'owners', which reflects their belonging to the land as much as the land belonging to them, and entails a special relation to the ancestral sources of its productivity. (I like what Sather (1990: 30) says about Iban in this connection, that the rice they raise is the transubstantiation of their ancestors.) Within the dualistic state, then, the indigenous people are not only the main subsistence producers, they also retain a preeminent spiritual authority over the land and corresponding ritual functions. But the stranger-kings trump the native people's original rights by aggressive and transgressive demonstrations of superior might and thus claim the sovereignty. The claim is also a promise

6 See among others: Heusch (1962, 1982a, 1982b); Kopytoff (1989); Balandier (1968a, 1968b); Ekholm (1978); Cunnison (1951); Forde and Kaberry (1967); Skinner (1964); Oberg (1970); EvansPritchard (1962); Southall (2004); Lombard (1965); Richards (1960).

7 Sabloff (2003); Carrrasco, Jones, and Sessions (2000); Gillespie (1989); and Stuart (2000), among others. 
of order and prosperity, for these stranger-heroes are ambiguous figures, both draconian and beneficent, whose untoward irruption into the native society in time becomes a civilising mission.

In traditions common in Africa and East Asia, the immigrant hero is the son of a powerful foreign king who fails to obtain the succession, perhaps for some fault that results in banishment from his native land. Or else, if he is not already marked by an antisocial past, his advent on the local scene is attended by incest, murder or other such crimes against kinship and morality. This 'exploit' as Luc de Heusch (1962) called it, by its transcendence of the local society, is a sign of the foreigner's power to organise it. In the ensuing time, the stranger-ruler is domesticated by the indigenous people, and his violence is turned outward toward the expansion of the realm; while internally, he bestows cultural benefits on the original owners that lift them from an initially rudimentary state.

The stranger-king is a rain-maker, both in the local sense that he fertilises the bearing earth of the native people and in our colloquial sense that, in contrast to their possession of land, he is the source of the society's riches, particularly in the form of life-enhancing foreign valuables. It is not for nothing that a number of Southeast Asian kingdoms were established by merchant princes, or that some of these were at the same time powerful religious figures, such as the rich Brahmin who founded the ancient Cambodian kingdom of Funan or the sayid traders who became prominent in Malay sultanates. As it is said in the Malay Annals (Sejarah Melayu), 'Where there is sovereignty, there is gold' (Brown 1952: 187). Providing foreign wealth and fertilising the land are of course parallel functions, insofar as both represent the vitality of alterity and comprise a necessary complement of external movable means for realising the fixed earthly powers of the indigenous people. This mutually beneficial conjunction is almost invariably accompanied by the union of the immigrant prince with a daughter of the indigenous ruler. Besides representing the reproductive synthesis of the foreign and the native directly in marriage, this union in the common case of patrilineal orders, by installing the stranger's lineage in power, is also a usurpation, thus making the formation of the polity an interesting mix of conflict and contract.

Typically, then, there is some continuing tension between the foreignderived royals and the native people. Invidious disagreements about legitimacy and superiority may surface in conflicting versions of the founding traditions, depending on which party for what purpose is telling 
the tale. (Hence the disputes about chiefly origins in Tikopia.) More than political, however, the synthesis of the foreign and the indigenous is cosmological, which is what helps it endure. Corresponding to the conjunction of an external masculinity and an internal femininity, the foreign rulers are to the native people in some such encompassing relation as the Celestial is to the Terrestrial, the Sea to the Land, the Wild to the Settled; or, in abstract terms, as the Universal is to the Particular, a ratio that also holds for their respective gods. We see, then, why the narratives of the advent of the stranger-hero function as all-round cultural constitutions. The union with the Other gives rise to the society as a selfproducing totality —and the permanent contradiction that this autonomy is a function of heteronymy.

A parenthetical note to place Tikopia in this general scheme, in addition to the aspects of stranger-kingship already mentioned: The devolution of rule on the immigrant Kafika ancestors, whether in divine or human form, rehearses the founding union of the foreign hero with a ranking woman of the indigenous people-in this case, several times over (Firth 1971). In the sequel to a liaison with a daughter of the Tafua lineage, a chiefly group that claims autochthonous origin, the Kafika usurp the Tafua as paramount chiefs. Another key Kafika marriage, this with a daughter of the autochthonous Faea people, is by all appearances (although no explicit statement) incestuous, as the woman had been married to her husband's father. The offspring of this transgressive marriage is the famous Atua I Kafika, the principal god and culture-hero of Tikopia, founder of its main institutions, including the ritual protocols of its prosperity. So in the event, the godly powers of the immigrant and incestuous strangers who marry the daughters and usurp the authority of the native rulers are domesticated and provide civilising benefits to the original Tikopia people. End of parenthesis.

\section{The politics of alterity}

Of course in a way, and as they say, all politics is local. But paradoxically the resources of political power in Austronesian societies and numerous others are generally foreign. I take Viveiros de Castro's point that, 'If humans were immortal, perhaps society would be confounded with the cosmos. Since death exists, it is necessary for society to be linked with something that is outside itself — and that it be linked socially to 
this exterior' (1992: 190-91). Ranging from beasts, spirits and gods to ineffable forces, by the way of the generic dead or the ancestors, and of other peoples with their remarkable gifts, the extraordinary agents that control the human fate live outside the space of human control. More precisely, the lack of control translates as being-in-other-space. I am speaking of the so-called and misnamed 'supernatural'. I say misnamed because the term supposes ethnocentric concepts of 'nature' and 'natural' - an autonomous world of soulless material things, of Cartesian res extensa-that are not pertinent to peoples who are engaged in a cosmic society of interacting subjects, including a variety of non-human beings with consciousness, soul, intentionality and other qualities of human persons.

Admittedly, my notions of the so-called 'supernatural' rest on simpleminded and old-fashioned premises. I take the rather positivist and Malinowskian view that people must in reality depend for their existence on external conditions not of their own making-hence and whence the spirits. Recall Malinowski's observation that magic comes into fishing in the Trobriands when one ventures beyond the reef. The going anthropological alternatives argue that divinity is some misrecognition of humanity. For Émile Durkheim, god is the misplaced apprehension of the power of society, a power people surely experience but know not wherefrom it comes. For a certain Marxist anthropology, god is an alienated projection of people's own powers of production and reproduction, an unhappy consciousness that has transferred human self-fashioning to the deity. Such theories may address the morphology of divinity, whether as reflection or mystification, but they do not tell us why society is set in a cosmos of beings invested with powers of vitality and mortality beyond any that humans themselves know or control, produce or reproduce. Neither sense of false consciousness takes sufficient account of the generic predicament of the human condition: this dependence on sui generis forces of life and death, forces not created by human science or governed by human intentionality.

If people really were in control of their own existence, they would not die. Or fall ill. Nor do they control the biology of sexual or agricultural generation. Or the weather on which their prosperity depends. Or, notably, the other peoples of their ken: peoples whose cultural existence may be enviable or scandalous to them. But in either case, by the very difference from themselves, ken are strangers who thus offer proof of a transcendent capacity for life. It is as if nothing foreign were merely human to them. Endowed with transcendent powers of life and death, the foreign becomes 
an ambiguous object of desire and danger. Hence the ubiquity - and ambiguity — of the aforementioned stranger-king formations. Dare one suggest that the much-maligned cargo cults are derived from the same general structures of alterity, except that they feature the people's own agency in appropriating the enriching powers of foreign subjects, by way of resistance, as it were, to a sovereign imposition.

In a way Josselin de Jong made the same point when he likened the initiation rites of the Toradja of Sulawesi, which entail taking an enemy head, to the foundation legend of the Negri Sembilan kingdom of Malaya by a Minangkabau stranger-prince from Sumatra (1969: 302-03; cf. Downs 1955). As famously reported for many Southeast Asian hinterland societies, these enemy heads, when ritually installed in the warrior's home community, become sources of the people's well-being, notably of the fertility of their crops-'for you', as Ifugao say to the enshrined head, 'have become one of us' (McKinley 1976: 115; cf. Hoskins 1996). Hence in respect of their beneficial effects as well as their initially hostile status, enemy heads are analogous to stranger-kings. Moreover, like the Minangkabau hero who successfully overcame dangerous adversaries on his way to seizing the kingship in Malaya, the young Toradja warrior acquires an exalted local status by his adventures in the realms of external-cumcosmic powers. In the charter narrative of the headhunting complex, the warrior-hero first undertakes an arduous trip to the Upperworld to exact revenge on the killers of his parents, and then descends to the Underworld to take the heads of his victims' ghosts. Corollary Toradja traditions tell that the village of the headhunter had been dead during his absence but revives upon his triumphal return, and that the hero also brings home the magical daughter of his victim and marries her after the head-feastthus transforming enemies into affines and marking their equivalence as reproductive agents. In sum, the Toradja warrior returns from a cosmic exploit with a foreign subject (the head) and enhanced reproductive virtue (the wife) in order to give life to (revive) the whole society. Allowance made for the inversions of stranger-king formations - the local hero who captures foreign power as opposed to the foreign prince whose power is captured locally - here is another modality of the same relationships.

Indeed one could say, at least in our colloquial terms, that the Iban of Borneo, in their raiding heyday, treated the heads of their victims royally, as something like stranger-kings. (For that matter, the symbolic killing of the royal heir as an outsider and his rebirth as a domestic ruler is 
a common feature of kingly installation rights in Oceania and elsewhere.) Consider, then, this nineteenth-century account of the Ibans' ritual regard for the enemy head, beginning with its debarkation from abroad:

The fleet, returning from a successful cruise, on approaching the village, announce to the inhabitants their fortunes by a horrid yell, which is soon imitated and prolonged by the men, women and children, who have stayed at home. The head is brought on shore with much ceremony, wrapped in the curiously folded and plaited leaves of the nipah palm, and frequently emitting the disgusting odour peculiar to decaying mortality; this, the Dyaks have frequently told me, is particularly grateful to their senses, and surpasses the odorous durian, their favorite fruit. On shore and in the village, the head, for months after its arrival, is treated with the greatest consideration, and all the names and terms of endearment of which their language is capable are abundantly lavished on it: the most dainty morsels ... is $[s i c]$ thrust into its mouth, and it is instructed to hate its former friends, and that, having been adopted into the tribe of its captors, its spirit must always be with them; sirih leaves and betel-nut are given it—and finally, a cigar is frequently placed between its ghastly and pallid lips. None of this disgusting mockery is performed with the intention of ridicule, but all to propitiate the spirit by kindness, and to procure its good wishes for the tribe, of whom it is now supposed to have become a member (Low 1848: 207).

Hugh Low and others writing of Iban at the time note that, like the Toradja, procuring a head was a necessary condition for obtaining a bride, although it appears that, even then, amassing heirloom wealth in a journey abroad (bejalai) was an alternative means.

Given that the rule of the stranger-king is not simply an imposition of foreign power but its beneficial integration on the part of the indigenous people, claims of external identity and potency are oft-used tactics of domestic political competition in Austronesian societies. Where foreign rulers become natives, so may natives become foreigners. I am not speaking simply of the estrangement of power: some sort of Clastrian contradiction between political authority and the common morality, the effect of which would be the ideological exile of the prince to the status of a foreigner. More fundamental is the structural dynamic that makes foreign identity a condition of indigenous authority. This can be a decisive move in the competitive process that Gregory Bateson (1958: 175ff) called symmetrical schismogenesis. 
Bateson sometimes likened symmetrical schismogenesis to an arms race in which each side tries to outdo the other by doing more of the same, on the principle of 'anything you can do I can do better'. At the extreme, however, competition in quantity is exchanged for competition in quality: one goes outside the box, trumping the adversary by shifting the terms of contention to means of another kind and a superior value, like introducing a new, devastating weapon into the arms race. So analogously in cultural politics-and not only among Austronesian peoples-the play is to outdo rival others by engaging transcendent powers in one's own cause, powers above and beyond the society and its customary bases of authority. Speaking of the Cook Islands, Jukka Siikala succinctly states the principle: 'The internal chiefly rivalry constantly seeks a means of legitimation outside its borders' (1996: 51).

Reported from all over the Austronesian world as the 'status rivalry' between older and younger brothers or senior and junior lines, and celebrated in tradition by conflicts that reverse their rank order, this politics of transcendence seem to be built into genealogically-ranked lineage systems. The effect of the inscribed 'principle of sinking status' is a structural disposition of junior kinsmen to transgress the established order, fated as they and their descendants are to decline in rank as their senior kinsmen increase in number (Geertz and Geertz 1975: 124ff). Hence the well-known opposition between inherited rank and demonstrated mana: between the ascribed and restrained dignity of the firstborn and the boundary-crossing, derring-do of the younger brother. The same appears in other registers as the triumph of the warrior (toa) over the chief (ariki) and the trickster over the greater gods (e.g. Smith 1974-75).

Gregory Schrempp (1992) brilliantly analysed this politics of transcendence as it appears in the well-known cosmogonic narrative of the Māori concerning the conflicts among the divine sons of Rangi (Heaven) and Papa (Earth). The younger-brother god Tü, ancestor of mankind, is able to defeat his elder sibling and celestial enemy Tawhiri, and by his victory Tū gains superiority over all his older brothers as well as control of the earthly species descended from them. Tawhiri was the only one of his siblings to join the Sky Father when the others forcefully separated their heavenly parent from the Earth Mother. In retaliation for this crime, Tawhiri let loose devastating squalls, whirlwinds and hurricanes on the earth, scattering the brothers hither and yon-which accounts for the distribution of natural species respectively sprung from them. Only Tū stood up to Tawhiri, battling him to a standstill. 'Tū alone was brave,' 
Māori say. And because his siblings had fled before Tawhiri, Tū then turned upon them, defeated and consumed them, rendering them inferior to himself. He became their senior brother. As Schrempp concluded, bravery is thus able to dominate as a political value, not merely as a physical force, because it is expressed and legitimated on a cosmic plane. Because Tù was victorious on this transcendent, heavenly plane, his human descendants are able to control the earthly species, including the staple foods, that instantiate his defeated brothers. The earthly privileges of the Māori are backed ultimately by higher cosmic values.

\section{The real-politics of the marvellous}

Recall, in this connection, Firth's correlation of an outburst of Tikopian overseas voyaging 'with the increasing realisation of the new worlds that lay beyond the horizon and the exciting experiences offered by contact with Europeans there' (1961: 152). Conversely, the early European visitors to Polynesian islands as it were brought heavenly power to earth, giving the people's traffic with them the character of ritual exchanges with ancient divinities. The records of Captain Cook's visits to Hawai'i offer several islander testimonies to this effect, such as Lt James King's notice of the common surmise that the great royal gods lived with the British:

As they certainly regarded us as a superior race of people to themselves, they would often say, that the great Eatooa [god] liv'd with us. The little Image .... they called Koonooe akai'a [Kunuiakea, principal god of the Hawai $i$ island paramount] \& said it was Tereeoboos [King Kalaniopu 'u's] God \& that he also liv'd with us (Beaglehole 1967: 621).

The same cosmography was in play in the assumption of foreign identities by ruling chiefs in several Polynesian societies, especially British identities and particularly that of 'King George' (III or IV), as though they were themselves stranger-kings. This tactic was practised notably by ambitious chiefs who could not claim by ancestry the authority to which they now aspired by force and wealth-with means largely acquired in trade with the Europeans they were pleased to take as models of their own power. The paramounts of three Hawaiian islands who named their sons and heirs 'King George', Iotete of the Marquesas who declared himself an Englishman, King George Tupou of Tonga, Hongi Hika of New Zealand, the Pomares of Tahiti: all these parvenu rulers sought to legitimate their sovereignty by assuming the trappings of foreign royalty (Sahlins 1994). 
The great Kamehameha, who usurped and sacrificed his senior royal kinsman (father's brother's son), the king of Hawai'i Island, and then went on to conquer the archipelago, considered George III his 'older brother' and addressed him so by letter. (I am repeating notices of Hawaiian chiefs' relations to Europeans that I have recorded elsewhere (Sahlins 1981b, 1992, 1995), begging your indulgence on grounds that the present context offers new insights into the meaning of these chiefly aspirations of alterity.) Kamehameha was flying the Union Jack from his house and canoe even before he ceded the Hawaiian Islands to 'King George', and he still considered himself under the British monarch's protection after the offer had been refused. In 1794, at the time he was campaigning to defeat the other Hawaiian rulers, Kamehameha lavishly hosted the British expedition captained by George Vancouver. As was his custom with passing European visitors, the Hawai i Island king was curious to know their manner of doing things, and he even posted a man to the galley of one of Vancouver's ships for the purpose of learning how to cook (a rare instance indeed of foreign regard for English cuisine). When Vancouver was preparing to leave, Kamehameha made several requests of the British to supply him with domestic furnishings and cooking utensils. Master's Mate Thomas Manby commented in his journal: 'and now that he was in possession of the requisites for the table, a tolerable cook and every kind of implement for culinary purposes, the monarch boasted with evident pride and satisfaction that he should now live like King George' (Manby 1929: 46).

Manby had already heard from a high priest that the Hawaiian ruling family traced their descent to Whitemen who had come to the islands some generations before-a story of ultimate connection to colonising Europeans of a kind told by indigenous peoples the world over. As if in confirmation, during the last years of Kamehameha's reign, John Adams Kuakini was governor of Hawai'i Island, Cox Ke'eamuoku ruled Maui, and Billy Pitt Kalaimoku was the 'Prime Minister' of the kingdom. These were not just sobriquets bestowed on Hawaiians by Europeans for their own amusement. Kalaimoku insisted on being called 'Pitt', and the casket in which Ke'eamuoku was buried in 1824 was simply inscribed 'Cox'. Also to be seen in Honolulu in those days were Billy Cobbett, George Washington, Charley Fox, Thomas Jefferson, James Madison and Napoleon Bonaparte. In 1819 when Kamehameha's widow and effective ruler of the Islands, Ka'ahumanu, declared the abolition of the traditional religion, she said that she and her people intended 'to live as the White 
people do'. The short story of the ensuing transformation of Hawaiian culture is that the ruling chiefs became Haole and the Haole, ruling chiefs_except for the American missionaries, such as Hiram Bingham; they became the chiefs' big kahunas.

Still, the greatest Haole success as an Austronesian ruler was that achieved by James Brooke, the 'White Rajah of Sarawak', who was ceded that position in 1841 by the rulers of Brunei and founded a British royal house in Borneo that lasted until World War II. ${ }^{8}$ By adroit diplomacy, the timely support of British warships, the encouragement of commerce and a certain divine potency, Rajah Brooke was able to gain complete independence from the Sultan of Brunei and to enlarge his own dominion over the indigenous Land and Sea Dayaks (Bidayuh and Iban). Brooke was, in effect, a foreign subject of marvellous powers that Malay aristocrats knew how to respect, if not how to resist, and native Borneo peoples vied one way or another to appropriate. Indeed there were probably many more than the one Iban who, according to the missionary wife Harriette McDougall, came to Kuching with the intention of taking the Rajah's head. Brooke's political manipulations and shows of force exacerbated the existing cleavages among Dayak groups, thus making his own enemies among the enemies of his friends. But those who opposed him would then have to fear the kind of calamities the Tikopia people attributed to the Bishop of Melanesia. Report has it that a powerful Iban chief, shortly before he died, gathered his people around him and exhorted them to give up 'piracy' because the failure of a recent raid as well as his approaching death, 'were all brought about by the supernatural powers of the Rajah of Sarawak, whom he said it was impossible to withstand' (Low 1848: 224).

On the positive side, Brooke was able to exploit the widespread reports of his beneficent spiritual powers in the Realpolitik of the marvellous by means of which he partly fashioned, largely extended, and regularly sustained his Sarawak kingdom. In fact, the reports of his extraordinary powers were spread far wider than his kingdom, let alone any empirical demonstration of his force or benevolence. Speaking of his own experience in the Borneo uplands in the early period of Brooke rule, Alfred Russel Wallace observed: 'Many of the distant tribes think that the Rajah cannot be a man. They ask all sorts of curious questions about him, whether

8 Brooke's ascent to power in Sarawak has been documented by many, both contemporaries and later historians, including: Low (1848); Keppel (1848); Mundy (1848); St. John (1879); Pringle (1970); and Walker $(1998,2002)$. 
or not he is as old as the mountains, whether he can bring the dead to life' (in Walker 1998: 98). But the indigenous people who knew Brooke personally could quiet any such curiosity by drawing directly on this lifegiving potency. Power could more or less literally be rubbed off him.

At a ceremony in which he installed a Bidayuh headman, Rajah Brooke noted that his own simungi and that of his ancestors were particularly invoked when spiritual presences were called upon, as well as the simungi of Malay notables, their ancestors, and the ancestors of the local people (Keppel 1848: 194). Simungi is the Bidayuh version of the Malay semangat, a soul-power particularly intense in high-ranking people, whence it can act in a mana-like way on the vitality of other persons (Endicott 1970; Skeat 1900). (Not to forget that in this highly animistic region, such other 'persons' include rice, pigs, fruit trees, celestial bodies, even some artefacts; hence the effects of the ruler's semangat may extend into what we call 'nature' or consider to be 'things'.) Under these circumstances, political submission is mediated by desires to acquire or participate in the ruler's semangat, which is why J.H. Walker can argue that Brooke's semangat was fundamental to his sovereignty. 'James Brooke was Rajah', he wrote, 'because so many in Sarawak recognized the intensity and expansiveness of his semangat and sought opportunities to engage it. This has been a fundamental process in state formation in Southeast Asia' (2002: 207)—notably, one might add, in connection with the installation of stranger-kings.

Brooke knew how to use his soul-power to political advantage. He found it 'highly gratifying' when the leaders of hinterland communities came to Kuching to obtain some of his bodily fluids, like the Bidayuh headman who 'brought me a young cocoa-nut for me to spit into, as usual; and after receiving a little gold dust and white cloth returned home to cultivate his fields' (Walker 2002: 116). Somewhat as a matter of course, Brooke noted that when he visited them, Dayak people would wash his hands and feet, and afterward sprinkle the bathwater on their houses and gardens.? Likewise for the gold and white cloth he presented — gifts they particularly desired of him-these too they planted in their gardens (Mundy 1848, v.2: 43). Several of Brooke's European companions and officials were treated in the same way, at least sometimes in virtue of their association with the Rajah.

9 A distant echo of Indian Buddhist practice? 
I rehearse a couple of these incidents here, leaving reference to others to a footnote.

Harriette McDougall's description (1854: 56-57) of the reception given to her husband Bishop McDougall and Rajah Brooke on the occasion of a visit to the Suntah Dyaks was apparently taken from the former's journal. The Englishmen were boisterously welcomed by the elaborately costumed old women of the group, who proceeded to stroke the visitors' arms and legs, 'for they fancy there is some goodness or virtue to be rubbed out of white people'. The women then washed McDougall's and Brooke's feet in coconut water, and set it aside 'to steep their paddy in, imagining it would help it to grow'. At night, some women stood over the sleeping Bishop, whom they knew to be a doctor, and repeatedly woke him by stroking his limbs and swaying their arms close to his face. The next day they 'brought portions of cooked rice on leaves, and begged the Englishmen to spit into them, after which they ate them up, thinking they should be the better for it' (cf. Walker 2002: 115-16).

In 1845, Hugh Low, the first European to visit the Land Dayak village of Sebongoh, was escorted from his boat on fine mats, and soon enough solicited by the headman (orang kaya) for a small piece of cloth and a silver coin that could be hung up in the longhouse to preserve the village from evil influence'. Later the headman, holding aloft a saucer of turmericdyed rice, required Low to repeat after him a prayer addressed to a major deity, the sun and the moon, and Rajah Brooke. The prayer requested 'that the next Padi harvest might be abundant, that their families might be increased with male children, and that their pigs and fowl might be very prolific: it was, in fact, a prayer for general prosperity to the country and tribe'. Low noted that when Brooke visited Bidayuh groups, they could achieve similar effects more directly by bringing rice seed into contact with him. Moreover, tribes too distant for Brooke to get to 'send down to him for a small piece of white cloth and a little gold or silver, which they bury in the earth of their farms, to attain the same result' (Low 1848: $254-59) .{ }^{10}$

10 For similar treatments of Brooke and other Europeans, see Low (1848: 224, 246-47, 251); St. John (1879: 230); Morris (1905: 166); and the notices compiled by Walker $(1998,2002)$ and Pringle (1970). In Malay Magic W.W. Skeat noted a like conflation of the powers of indigenous rulers and European colonial agents (1900: 36-37). 
Among other classic features of stranger-kingship, note in these descriptions that 'where there is sovereignty, there is gold'. Rajah Brooke \& Co. are solicited for the mobile wealth that potentiates the reproductive capacities of the native people- such as the gold dust that could be showered like rain on the swidden fields of the indigenous owners. Implying direct contact with his person, the gifts of cloth would have the same fertilising virtue. Brooke was also known to present Malay officials and Dayak leaders with costumes of office, sometimes including decorated loincloths. The nakedness of the native rulers was thus encompassed and sublimated by the foreign king, they were at once civilised and empowered. In a related cosmic register, that of the founding union of the stranger-king with the daughter of his native predecessor, stories circulated about the liaisons of Rajah Brooke with important Malay and Dayak women. According to one (unconfirmed) report, Brooke married the niece (brother's daughter) of the Malay noble who originally ceded Sarawak to him (D.E. Brown 1970). The Iban had even less-verifiable and more marvellous stories of Brooke's relations to their own cosmogonic deities. Some comprehended him by the topos of the returning ancestral-stranger (like the $\mathrm{Pu} \mathrm{Ma}$ twins of Tikopia), saying he was the son of their primordial mother and father, Kumang and Keling. Others said Brooke was not Kumang's son but her lover, and that he was in the habit of climbing Mt Santugong to make love to her-a magnified feat of union with the ranking woman of the people. Yet, for all that the structures of stranger-kingship order such narratives, Brooke's history suggests that they did so not in some necessary or predetermined way, but only through the particular agencies and contingencies they empowered.

Structure on one hand, agency and contingency on the other, are not here (or anywhere) opposed historical determinants in the sense that they exclude one another. On the contrary, each is the condition of the historical possibility of the other. In authorising particular persons and circumstances as historical difference-makers, the structural order is a sine qua non of their efficacy, though it is not responsible for their particularities, nor then for the difference they will make. In Sartrian terms, particularity is an irreducible way of living universality or the structure of the collectivity; and accordingly the collectivity must live through the attributes of the persons and things on which it has made itself dependent (Sartre 1963: 130). Hence the possibility of historical outcomes that are structurally consistent and evenementially variable. Between the structural order of the historical situation and what actually 
happens there is no necessary relation. Rather, the structure is realised in a particular historical form by the mediation of the contingencies it has empowered. So while one may justly conclude that the transcendent potencies ascribed to James Brooke allowed him to become the Rajah of Sarawak, he could have just as easily been assassinated for the same reasonby a rival Malay leader, for example, or some Dayak headhunter. (Perhaps nowhere more than in Dayakland, uneasy lies the head that wears the kingly crown.) Brooke's death would have followed from, and realised, the same concepts of the potency of alterity that had made him the rajah-for they also defined his enemies.

A certain Scotsman, Erskine Murray, came to just such an untimely end in 1843 when he tried to duplicate Brooke's feat by entrenching himself in the Sultanate of Kutei in south Borneo. Murray had not reckoned on the powerful Bugis sea-warriors who were already established there, nor on the Sultan's capacity for armed resistance. Compounding this unfavourable correlation of forces by his own maladroit diplomacy, Murray was killed as he tried to flee downriver-on one of the two heavily-armed trading vessels by means of which he had hoped to back his ambitions of rajahdom (Low 1848: 103; Saunders 1980).

Murray was not the only would-be European rajah on the Borneo coasts during the mid-nineteenth century, nor was Brooke the only foreigner to successfully rule there. Graham Saunders (1980) and J.H. Walker (2002) described a number of such western adventurers, most of whom failed badly although their projects were similar to the one James Brooke brought off. Nor were these men the first to try. Borneo had a considerable history of stranger-kings: mainly Malay, Javanese and Sumatran traders or aristocrats, as well as a number of Arabian-derived sharifs or sayids, who took over or carved out principalities of their own. ${ }^{11}$ Sharif Abdul Rahman, who with Dutch support and a title bestowed by the Rajah of Riau founded the Sultanate of Pontianak south of Brunei, became known to historians as 'an Arab James Brooke' from the similarity of their royal careers. 'With the substitution of Dutch for English and Abdul Rahman for Brooke [and the Raja of Riau for the Sultan of Brunei], this is essentially the story of Sarawak, set only seventy years earlier' (Pringle 1970: 61).

11 On merchant-princes in coastal Southeast Asia, see Manguin (1991). Although not ruling kingdoms of their own, a considerable number of European merchant-adventurers, as also Chinese, Indians and other foreigners, held high offices in traditional Southeast Asian and Indonesian principalities (Reid 1994, 2008). 
Again, the legendary charter of the Brunei Sultanate, from which Brooke wrested his Sarawak kingdom, tells of a series of stranger-king dynastiesin terms that by now should be quite familiar (D.E. Brown 1970, 1973; Hughes-Hallett 1981). According to the traditions recorded by D.E. Brown, Brunei was founded by 14 brothers, born of a celestial fatherwho descended in an egg from Kayangan, the heaven of old Indonesian gods - and autochthonous mothers, women from the various riverine districts the heavenly hero visited. One of the brothers became the first Sultan of Brunei by virtue of a union with the daughter of the powerful Sultan of Johor, apparently a hypogamous marriage that differentiated this Borneo line by its prestigious affinal connections. The successor of the first Brunei Sultan was either Chinese himself or else married a Chinese woman, according to the version. (In either case, taking the same principle of affinally derived prestige into account, the Brunei ruler would be endowed with extraordinary foreign powers.) Finally, in what seems a foreshortened version of a longer royal narrative, the third Sultan of Brunei was an Arabic sharif who 'married the daughter of the second Sultan and strengthened Islam in Borneo' (D.E. Brown 1973: 114). ${ }^{12}$

With regard to the attempts of other Europeans to win kingdoms in the manner of Rajah Brooke, there were of course differences among them in character, knowledge and judgement that contributed to the various political results. The historians also speak to certain long-term and short-term contingencies that came into play in connection with these individual expressions of the European libido dominandi. For example, the hiatus in collective imperial enterprises - in the period between the entrepôt colonialism that ended around 1819 (with the termination of the Napoleonic wars) and the territorial imperialism of the 1870 s and $80 \mathrm{~s}$ - was a period of relative neglect by western powers that offered the space for individual ambitions the likes of Rajah Brooke's. Yet Brooke himself would have gone down in the 1840s or 50s were he not rescued by British gunboats that had only lately come into the region because of the Chinese opium wars. Call it 'timing' or 'luck', the point is that certain

12 Something like the rise and fall of the Chinese dynasty of Brunei is told in the legend of the mountain, Kina Bulou, 'Chinese Widow' in North Borneo. Hugh Low (1848: 6-7) related the story, as he had it from 'the Rajahs of Borneo'. In the time before the conversion to Islam, the summit of Kina Bulou was the home of a beautiful spirit woman of whom a Chinese prince of Brunei was enamoured. But on his attempt to reach the summit and marry her, the prince fell off the mountain and was killed. Thereafter the spirit woman was called the 'Widow of the Chinese' and the mountain was named after her. Compare the Brunei traditions with the 'China, White Malaya' stranger-kings of the Southern Tetuns (van Wouden 1968: 46-47). 
systemic relations of alterity and autochthony were realised in a unique way because of their engagement with circumstances whose own causes lay elsewhere.

The deaths of Captain Cook (aka 'Lono') at Hawai' $i$ and the Reverend John Williams (aka 'Nobu') at Erromanga are perhaps more familiar instances of the same interaction of structure and contingency (Sahlins 2000: 415, 456). Both of these powerful foreigners were identified in stranger-king terms as the returning forms of original native gods andtalk of timing! - - both arrived at the annual rituals of the god's fertilising passage through the land, which is also his temporary repossession of it. In Cook's case we know for sure that this involved a certain rivalry with King Kalaniopu'u of Hawai'i Island-their opposition was built into the Makahiki (New Year) rituals - and that rivalry became fateful for Cook the morning he tried to take the king hostage against the return of a stolen ship's cutter. Yet of all the myriad contingent factors that contributed to the fatal outcome, including Cook's irascibility and his practised hubris with Polynesian chiefs, they would have been irrelevant were it not for the storm that damaged the Resolution's mast and forced him to return structurally out-of-season. And that in turn would have had a different and more benign sequel if Cook had known how to swim, and thus escape from the confrontation with the defenders of the king, as had most of the marines who were ashore with him (Sahlins 1995). Again, the big argument I am making is that Cook was a god-figure who died as a function of the same kind of structural relations that allowed Brooke to be the man who became king.

Finally, speaking of 'The Man Who Would Be King', Kipling's short story of the Englishman who became an Asian potentate because the local people took him to be a descendant of Alexander the Great turns out to be a genre of romantic non-fiction in the Malay Peninsula, Sumatra and Borneo, where ruling Islamic sultans did actually claim Alexandrian ancestry. ${ }^{13}$ But to back-track a bit: the historical Alexander III of Macedonia had already been a stranger-king in his own realm. According to their own royal traditions, the Argead rulers of Macedonia descended from the Heraclid kings of the Peloponnesus; and Alexander,

13 On Alexander the Great and the many Alexandrian Romances see: Arrian (1991); Curtius (1946); Diodorus of Sicily (1963); Plutarch (1915, 1936); Stoneham (1991); Leeuwen (1937); Polignac (1982); Southgate (1978); Pseudo-Callisthenes (1969); Winstedt (1938); Cartledge (2004); Burn (1962); Green (1991); Mossé (2004); Anderson (1932); Thomas (2007). 
moreover, doubled his exalted derivation from Heracles on his father's side by his reputed descent from Achilles on his mother's. Alexander's father, Phillip, had greatly enlarged Macedonia by successful wars against neighbouring kings-whose daughters he regularly took to wife. And to fill out the stranger-king topos, the Argeads were civilisers. At a time during his Asian campaigns when Alexander had occasion to rebuke his Macedonian soldiers for ingratitude, he reminded them that his royal father had transformed them from a weak bunch of nomads wandering the mountains with their pitiful herds of sheep into trained warriors and properly clad, well-ordered city-dwellers of the Macedonian plains. Literally, he civilised them: 'He defined you as residents of cities and arranged good laws and customs' (Arrian 1991, VII.9: 2-3). But at the moment Alexander made this speech, he was on his way to becoming a stranger-king of world-historical proportions.

For by building cities from Egypt to Afghanistan, Hellenising the local populations, adopting the customs and costumes of defeated rulers, and marrying their daughters, Alexander reproduced the stranger-king scheme on a grand scale-leaving in his wake foreign dynasties of the same character, notably the Ptolemys and Seleucids. Tradition has it that Alexander carried a copy of the Iliad annotated by his tutor Aristotle on his campaigns, and according to Plutarch, he made it common reading among Asians, as well as setting their sons to reciting the tragedies of Sophocles and Euripides. Bringing Asians into such civilised community with Greeks could not have pleased Aristotle, who held Barbarians to be natural slaves. On the other hand, in constructing cities, making laws and otherwise taming the 'savagery' of Asian peoples, Alexander would be following Aristotelian prescriptions for repressing the appetitive soul by good education and legislation. In a work that perhaps should be placed with the many romances of Alexander, Plutarch says the Macedonian hero persuaded the Sogdians to support their parents instead of killing them, the Persians to respect their mothers instead of marrying them, and the Scythians to bury their dead instead of eating them. And this, said Plutarch, made him a great philosopher in his own right. For if philosophers take the greatest pride in civilising the untutored elements in human character, 'and if Alexander has been shown to have changed the savage natures of countless tribes, it is with good reason that he should be regarded as a very great philosopher' (Plutarch Fortuna I.5). 
In the Islamic Romances of Alexander-Persian, Turkish and Arabic as well as Malay-the hero was identified with Iskandar Dzu'l-karnian of Koranic fame, a militant propagator of the Faith from the setting to the rising sun. Iskandar's conquests were not only of the same scope and direction as Alexander's, but he was likewise a civiliser, if in this case by Islamicising the Infidels rather than Hellenising the Barbarians. According to the Malay Romance (Winstedt 1938; Leeuwen 1937), Iskandar had been taught the Koran by Aristotle of Istanbul, a figure who generally appears in the Islamic versions as the conqueror's political adviser or vizier. As was then documented in local chronicles and traditions of the classic stranger-king form, the descendents of Alexander/Iskandar become the sultans of various states in the Malay Peninsula, Sumatra and coastal Borneo.

A key account of the Iskandar tradition appears in the Malay Annals (Sejarah Melayu), a text formulated on behalf of the rulers of the once flourishing commercial state of Melaka, apparently compiled shortly after the fall of that city to the Portuguese in 1511 (C.C.E. Brown 1952). O.W. Wolters $(1970,1986)$ persuasively argues that the adoption of the Alexandrian tradition functioned to legitimate Melaka as true successor of the ancient kingdom of Srivijaya in Sumatra, as against the claims of the trading centre of Malayu-Jambi. Srivijaya had in fact declined in the eleventh century and lost supremacy on the southern Sumatran coast to the rajas of Malayu-Jambi. But the Malay Annals would effectively erase Malayu-Jambi from historical memory by making the founder of Melaka a descendant in the fifth generation of one Sri Tri Buana, a heroic prince of Alexandrian lineage who miraculously appeared near the Srivijaya capital and became its ruler. Besides this direct genealogical connection to Srivijaya, by their privileged descent from the Islamic world-conqueror Iskandar/Alexander, the Sultans of Melaka would also trump MalayuJambi on a cosmic religious plane. Here is a clear example of transcendental schismogenesis on an interstate level.

To summarise the Melaka charter narrative in a radically abbreviated form. Three handsome youths in stunning royal garb appear on a mountain above Palembang, the ancient capital of Srivijaya. As in many traditions of stranger-kings, the youths miraculously bestow great wealth on the native people, here represented by the two widowed women who discover them, by turning the mountain top into gold and the rice fields to gold and 
silver. ${ }^{14}$ When it is learned that the youths are descended from Alexander the Great, people come from various Malay states to take them as their king. The youngest, Sri Tri Buana, is so acknowledged by the Raja of Palembang. (Commenting on traditions of royal succession in Western Indonesia, Josselin de Jong (1980) observes that the junior son usually takes precedence.) But Sri Tri Buana is not formally installed as ruler in Palembang until the native Raja is able to neutralise a certain malevolent power manifested by the godly stranger. All of the 39 princesses who are brought to Sri Tri Buana as wives come down with a disfiguring skin condition (chloasma) upon sleeping with him. When Sri Tri Buana then asks for the hand of the Raja's beautiful daughter, the native ruler imposes the condition that the stranger will never shame or disrespect his subjects, in return for which the Raja promises eternal loyalty. This contract concluded, the marriage takes place without ill effect, Sri Tri Buana is installed as ruler, and the Raja becomes his chief minister. ${ }^{15}$

In a few generations the lineal successors of Sri Tri Buana would found Melaka, convert to Islam, and become sultans of a prosperous commercial kingdom. They and the other rulers tracing descent to Alexander the Great thereby inherited powers of global dimensions, world-dominating powers, originating in the great centre of 'Rum'-referring usually to Istanbul and the Ottoman emperors, but sometimes to Rome or Macedonia. On an edict issued in the late eighteenth century by a Sultan of Minankabau were affixed three seals representing three sons of Alexander/Iskandar: the Sultan of Rum, the oldest; the Sultan of China, the second; and himself, Sultan of Minankabau, the youngest and 'king of kings ... lord of the air and clouds ... possessed of the crown of heaven brought by the prophet Adam' (Marsden 1811: 339). ${ }^{16}$

14 Note the recurrent Indonesian form of the greeting of the stranger-king by older women, widowed or post-menopausal-for reasons I do not know.

15 This sort of diarchy consisting of an immigrant sacred ruler and an active second king from the indigenous people is also found in ethnographies of eastern Indonesia and as far off as Fiji. Permutations in Indonesia include immigrant warrior second kings such as the Bugis in the Straits area and sacred sayid second kings in Malaya and Sumatra.

16 Anthony Reid (2008: 254) points out that 'almost all rulers of [Sumatran] coastal port states proudly traced their origin to a mighty foreign ruler, of whom the epitome for Muslims was the world-conqueror Iskandar Zulkarnain (Alexander the Great). Malay rulers sought to trace their descent from this ultimate source, though often mixed with more probable antecedents associated with the Middle East (Raja Rum) or India (Raja Kalinga or Vijaynagar)'. 
The Alexandrian tradition in Indonesia is linked to many more narratives of the marvellous, some of epic proportions; I will only mention a couple by way of conclusion. Sri Tri Buana's mother was the daughter of the King of the Sea, whom his father had married when he went under the ocean and thereby succeeded to the rule of that underwater realm. One is reminded of the Queen of the South Sea, the mystical bride of legitimate Javanese kings, herself descended in the ruling line of the ancient Sundanese kingdom of Pajajaran. Another Javanese hero, Baron Iskandar-whose moniker, as Anthony Reid (1994: 92) points out, combines a European title with the Javanese name for Alexander the Great-had a brother who also married a Pajajaran princess, and among their offspring was J.P. Coen, the Governor General of the Dutch East India Company, who established its headquarters at Batavia in 1619. Baron Iskandar himself, who in his career was a stranger-king of Spain before conquering the lands from Arabia to China, eventually winds up in the service of the Islamic ruler of Mataram - thus proving the superiority of that Javanese state to the intruding Dutchmen (Ricklefs 1974: 373ff).

It seems that these are so many more instances of a structure without an event, an unmotivated history, since none of this was 'what actually happened'. Yet not exactly, for as Raymond Firth observed of the new vistas of wealth and power opened to Tikopians by the advent of Europeans, or as the Hawaiian chiefs who identified with the likes of King George, John Adams, and Billy Pitt, so did people of the Malay archipelago enter into an expanded cosmography of the marvellous, centred in Rum, by virtue of Ottoman, Persian and Arabian commerce. Taken together, these examples show that modern European imperialism has not been the only source of the local desires of alterity. Nor are such desires ever a simple function of outside domination. Here is a further proof, if one is now needed, that in speaking of 'acculturation' we must consider from the beginning the role of indigenous agency. The Austronesian peoples have always known their own internal dynamics of transcendence: desires of alterity and quests of potency that in all probability led to their remarkable feats of voyaging and their settlement of distant islands - as far into the sky beyond the horizon as Madagascar and Easter Island. So far could their real-politics of the marvellous take them. 


\section{References}

Andaya, Leonard. 2006. 'The stranger-king complex in Bugis-Makassar society'. Paper presented at conference on 'Stranger-Kings in Southeast Asia and Elsewhere', Jakarta, 5-7 June 2006.

__ 1975. 'The nature of kingship in Bone'. In Pre-colonial State Systems in Southeast Asia: The Malay Peninsula, Sumatra, Bali-Lombok, South Celebes, Monographs of the Malaysian Branch of the Royal Asiatic Society No. 6, ed. Anthony Reid and Lance Castles, pp. 115-125. Kuala Lumpur: Malaysian Branch of the Royal Asiatic Society.

Anderson, Andrew Runni. 1932. Alexander's Gate, Gog and Magog, and the Inclosed Nations. Cambridge, MA: Medieval Academy of America.

Arrian. 1991. Anabasis of Alexander, 2 vols. Loeb Classical Library. Cambridge, MA: Harvard University Press.

Backus, Charles. 1981. The Nan-chao Kingdom and T'ang China's Southwestern Frontier. Cambridge: Cambridge University Press.

Balandier, Georges. 1968a. Daily Life in the Kingdom of Kongo: From the Sixteenth to the Eighteenth Century. New York: Pantheon Books.

—_. 1968b. Anthropologie Politique. Paris: Presses Universitaires de France.

Barnes, R.H. 1974. Kedang: A Study of the Collective Thought of an Eastern Indonesian People. Oxford: Clarendon Press.

Bateson, Gregory. 1958. Naven, 2nd edition. Stanford: Stanford University Press.

Beaglehole, J.C. (ed.). 1967. The Journals of Captain James Cook on his Voyages of Discovery, Vol III: The Voyage of the Resolution and Discovery, 1776-1780. Cambridge: Cambridge University Press for the Hakluyt Society.

Bernart, Luelen. 1977. The Book of Luelen. Canberra: The Australian National University Press.

Bowen, John R. 1991. Sumatran Politics and Poetics: Gayo History, 1900-1989. New Haven: Yale University Press. 
Briggs, Lawrence Palmer. 1951. The Ancient Khmer Empire. Philadelphia: Transactions of the American Philosophical Society. doi. org/10.2307/1005620.

Brown, C.C.E. 1952. "The Sejarah Melayu or "Malay Annals": A translation of Raffles MS 18'. Journal of the Malayan Branch of the Royal Asiatic Society 25: 7-276.

Brown, D.E. 1973. 'Hereditary rank and ethnic history: An analysis of Brunei historiography'. Journal of Anthropological Research 29(2): 113-22. doi.org/10.1086/jar.29.2.3629986.

- 1970. Brunei: The Structure and History of a Bornean Malay Sultanate. Brunei: Brunei Museum.

Burn, A.R. 1962. Alexander the Great and the Hellenistic World. New York: Collier Books.

Carrasco, David, Lindsay Jones and Scott Sessions (eds). 2000. Mesoamerica's Classic Heritage: From Teotihuacan to the Aztecs. Boulder: University Press of Colorado.

Cartledge, Paul. 2004. Alexander the Great: The Hunt for a New Past. New York: Vintage Books.

Coedès, George. 1968. The Indianized States of Southeast Asia. Honolulu: University of Hawai'i Press.

Cunnison, Ian. 1951. History on the Luapula: An Essay on the Historical Notions of a Central African Tribe. Capetown: Rhodes Livingstone Institute.

Curtius. 1946. Histories. Loeb Classical Library. Cambridge MA: Harvard University Press.

Diodorus of Sicily. 1963. Library of History, Book XVII. Loeb Classical Library. Cambridge MA: Harvard University Press.

Downs, R.E. 1955. 'Headhunting in Indonesia'. Bijdragen tot de Taal-, Land-en Volkerkunde 111: 40-70. 
Ekholm, Kajsa. 1978. 'External exchange and the transformation of central African social systems'. In The Evolution of Social Systems, ed, J. Friedman and M.J. Rowlands, pp. 115-36. Pittsburgh: University of Pittsburgh Press.

Endicott, Kirk. 1970. An Analysis of Malay Magic. Oxford: Clarendon Press.

Evans-Pritchard, E.E. 1962. 'The divine kingship of the Shilluk of the

Nilotic Sudan'. In Essays in Social Anthropology, ed. E.E. EvansPritchard, pp. 66-86. London: Faber and Faber.

Firth, Raymond. 1970. Rank and Religion in Tikopia: A Study in Polynesian Paganism and Conversion to Christianity. London: Allen \& Unwin.

- 1967 . The Work of the Gods in Tikopia, 2nd edition. London: Athlone Press.

—_. 1961. History and Traditions of Tikopia. Wellington: Polynesian Society.

—_. 1957. We, the Tikopia: A Sociological Study of Kinship in Primitive Polynesia, 2nd edition. London: George Allen \& Unwin.

—_. 1950. Primitive Polynesian Economy. New York: Humanities Press.

Fiskesjö, Magnus. 1999. 'On the "raw" and the "cooked" barbarians of imperial China'. Inner Asia 1: 139-68. doi. org/10.1163/146481799793648004.

Forde, Daryll and P.M. Kaberry (eds). 1967. West African Kingdoms in the Nineteenth Century. London: Oxford University Press.

Fox, James J. 2006. 'Precedence, diarchy and stranger-kings in the Timor area'. Paper presented at conference on 'Stranger-Kings in Southeast Asia and Elsewhere', Jakarta, 5-7 June 2006.

—_. 1995a. 'Instituting the "outside" inside: The exploration of an epistemic Austronesian cultural theme and its social significance'. Revised and extended draft of a paper presented at the first European Association for Southeast Asia Studies Conference, Leiden, 29 June1 July 1995. 
- 1995b. 'Austronesian societies and their transformations'. In The Austronesians: Historical and Comparative Perspectives, ed. Peter Bellwood, James J. Fox and Darrell Tryon, pp. 214-28. Canberra: Department of Anthropology, Research School of Pacific and Asian Studies, The Australian National University.

Frazer, James George. 2006. The Golden Bough. Sioux Falls, SD: New Vista Publications.

Geertz, Hilda and Clifford Geertz. 1975. Kinship in Bali. Chicago: University of Chicago Press.

Gibson, Thomas. 2005. And the Sun Pursued the Moon: Symbolic Knowledge and Traditional Authority Among the Makassar. Honolulu: University of Hawai'i Press.

Giersch, C. Patterson. 2006. Asian Borderlands: The Transformation of Qing China's Yunnan Frontier. Cambridge MA: Harvard University Press.

Gillespie, Susan D. 1989. The Aztec Kings: The Construction of Rulership in Mexica History. Tucson: University of Arizona Press.

Glahn, Richard von. 1987. The Country of Streams and Grottoes: Expansion, Settlement and the Civilizing of the Sichuan Frontier in Song Times. Cambridge, MA: Council on East Asian Studies, Harvard University.

Goodenough, Ward H. 1986. 'Sky world and this world: The place of Kachaw in Micronesian cosmology'. American Anthropologist 88: 551-68. doi.org/10.1525/aa.1986.88.3.02a00010.

Green, Peter. 1991. Alexander of Macedon 356-323 B.C.: A Historical Biography. Berkeley: University of California Press.

Hanlon, David. 1988. Upon a Stone Altar: A History of the Island of Pohnpei to 1890. Pacific Island Monographic Series No. 5. Honolulu: University of Hawai'i Press.

Heine-Geldern, Robert von. 1956. 'Conceptions of State and Kingship in Southeast Asia'. Southeast Asia Program Data Paper No. 18. Ithaca: Cornell University Press.

Heusch, Luc de. 1982a. Rois nes d'un coner de vache. Paris: Gallimard. 
1982b. The Drunken King, or the Origin of the State. Bloomington: Indiana University Press.

—_. 1962. 'Aspects de la sacralité du pouvoir en Afrique'. In Le pouvoir et le sacré, ed. Luc de Heusch et al., pp. 139-58. Bruxelles: Institut de Sociologie, Université Libre de Bruxelles.

Ho, Engseng. 2002. 'Before parochialization: Diaspora Arabs cast in Creole waters'. In Transcending Borders: Arabs, Politics, Trade and Islam in Southeast Asia, ed. Huub de Jonge and Nico Kaptein, pp. 11-35. Leiden: KITLV Press.

- - 1999. 'Transformation and reformation of Malay polity and identity'. MA thesis, Department of Anthropology, Division of the Social Sciences, University of Chicago.

Hocart, A.M. 1929. Lau Islands, Fiji. Bernice P. Bishop Museum Bulletin No. 62. Honolulu: Bishop Museum.

Horstmann, Alexander and Reed L. Wadley. 2006. Centering the Margin: Agency and Narrative in Southeast Asian Borderlands. New York: Berghahn Books.

Hoskins, Janet. 1996. Headhunting and the Social Imagination in Southeast Asia. Stanford: Stanford University Press.

—— 1993. The Play of Time: Kodi Perspectives on Calendars, History, and Exchange. Berkeley: University of California Press.

Hughes-Hallett, H.R. 1981. 'A sketch of the history of Brunei'. Brunei Museum Journal 5(1): 1-18.

Josselin de Jong, P.E. de. 1980. 'Ruler and realm: Political myths in western Indonesia'. Mededelingen der Koninklijke Nederlandse Akademie van Wetenschappen, Afd. Letterkunde 43(1): 1-19.

—_. 1975. 'The dynastic myth of Negri Sembilan (Malaya)'. Bijdragen tot de Taal-, Land-en Volkerkunde 131: 277-308.

—_. 1969. Contact der Continenten, Leiden: Leiden Univeristy Press.

Kasetsiri, Charnvit. 1976. The Rise of Ayudhya: A study of Siam in the Fourteenth and Fifteenth Centuries. Kuala Lumpur: Oxford University Press. 
Kathirithamby-Wells, Jeyamalar. 2006. 'Stranger-kinsmen as strangerkings in eighteenth- and nineteenth-century, Perak, Siak, and Pontianak'. Paper presented at conference on 'Stranger-Kings in Southeast Asia and Elsewhere', Jakarta, 5-7 June 2006.

Keppel, Henry. 1848. The Expedition to Borneo of H.M.S. Dido for the Suppression of Piracy; with Extracts from the Journal of James Brooke, Esq., of Sarawak. New York: Harper \& Bros.

Kopytoff, Igor. 1989. 'The internal African frontier: The making of African political culture'. In The African Frontier: The Reproduction of Traditional African Societies, ed. Igor Kopytoff, pp. 3-84. Bloomington: Indiana University Press.

Krizancic, Catarina. 2006. 'The rise of the House of Salmon: Before and beyond French Tahiti, 1842-present'. PhD dissertation draft, Department of Anthropology, University of Chicago.

Leach, Edmund. 1954. Political Systems of Highland Burma. Cambridge, MA: Harvard University Press.

Leeuwen, P.J. 1937. De malaische Alexanderroman. Meppel: B. Ten Brink.

Lehman, F.K. 1963. The Structure of Chin Society: A Tribal People of Burma Adapted to a Non-western Civilization. Urbana: University of Illinois Press.

Li, Tania Murray. 2001. 'Relational histories and the production of differences in Sulawesi's upland frontier'. The Journal of Asian Studies 60(1): 41-66. doi.org/10.2307/2659504.

Lingenfelter, Sherwood. 1975. Yap, Political Leadership and Culture Change in an Island Society. Honolulu: University of Hawai' i Press.

Lombard, Jacques. 1965. Structures de type féodal' en Afrique noire: étude des dynamismes internes et des relations sociales chez les Bariba du Dahomey. Paris: Mouton.

Low, Hugh. 1848. Sarawak; its Inhabitants and Productions: Being Notes during a Residence in that Country with H.H. the Rajah Brooke. London: Richard Bentley.

Malinowski, Bronislaw. 1948. Magic, Science and Religion and other Essays. Boston: Beacon Press. 
Manby, Thomas. 1929. 'Journal of Vancouver's voyage to the Pacific Ocean'. Honolulu Mercury 1(3): 39-55.

Manguin, Pierre-Yves. 1991. 'The merchant and the king: Political myths of Southeast Asian coastal polities'. Indonesia 52: 41-54. doi. org/10.2307/3351154.

Marsden, William. 1811. The History of Sumatra, 3rd edition. London: Printed for the author by J. McCreery, Black-Horse Court.

McDougall, Harriette. 1992. Sketches of our Life at Sarawak. Singapore: Oxford University Press.

—_. 1854. Letters from Sarawak: Addressed to a Child. Norwich: Thomas Priest.

McKinley, Robert. 1976. 'Human and proud of it! A structural treatment of headhunting rites and the social definition of enemies'. In Studies in Borneo Societies: Social Process and Anthropological Explanation, ed. G.N. Appell, pp. 92-126. DeKalb: Center for Southeast Asian Studies, Northern Illinois University.

Morris, Margaretta. 1905. 'Harvest gods of the Land Dayaks of Borneo'. Journal of the American Oriental Society 26: 165-75. doi. org/10.2307/592888.

Mossé, Claude. 2004. Alexander: Destiny and Myth, trans. Janet Lloyd. Baltimore: Johns Hopkins University Press.

Mundy, Rodney. 1848. Narrative of Events in Borneo and Celebes ... From the Journals of James Brooke, Esq, Rajah of Sarawak and Governor of Labuan. London: John Murray.

Oberg, K. 1970. 'The kingdom of Ankole in Uganda'. In African Political Systems, ed. Meyer Fortes and E.E. Evans-Pritchard, pp. 121-64. London: Oxford University Press for the International African Institute.

Parmentier, Richard. 1987. The Sacred Remains: Myth, History, and Polity in Belau. Chicago: University of Chicago Press.

Petersen, Glenn. 1990. Lost in the Weeds: Theme and Variation in Pohnpei Political Mythology. Honolulu: Center of Pacific Studies, University of Hawai'i at Mānoa. 
Plutarch. 1936. Moralia, vol. 4. Loeb Classical Library. Cambridge, MA: Harvard University Press.

—. 1915. Lives: The Dryden Plutarch, vol. 2, revised by Arthur Hugh Clough. London: Everyman.

- Fortuna I (On the fortune of Alexander). Alexander Sources. Online: www.sites.google.com/site/alexandersources/plutarch/ (accessed 1 March 2017).

Polignac, François de. 1982. 'L'image d'Alexandre dans la littérature Arabe. L'Orient face à l'Hellénisme?' Arabica 29(2): 296-306. doi. org/10.1163/157005882X00310.

Preaux, Jean-G. 1962. 'La sacralité du pouvoir royal à Rome'. In Le pouvoir et le sacré, ed. Luc de Heusch et al., pp. 103-122. Bruxelles: Institut de Sociologie, Université Libre de Bruxelles.

Pringle, Robert. 1970. Rajahs and Rebels: The Ibans of Sarawak under Brooke Rule, 1841-1941. Ithaca: Cornell University Press.

Pseudo-Callisthenes. 1969. The Romance of Alexander the Great by PseudoCallisthenes, trans. and ed. Albert Mugrdich Wolohojian. New York: Columbia University Press.

Reid, Anthony. 2008. 'Merchant princes and magic mediators'. Indonesia and the Malay World 36(105): 253-67. doi. org/10.1080/13639810802268007.

—. 1994. 'Early Southeast Asian categorizations of Europeans'. In Implicit Understandings: Observing, Reporting and Reflecting on the Encounters Between Europeans and Other Peoples in the Early Modern Era, ed. Stuart B. Schwartz, pp. 268-94. Cambridge: Cambridge University Press.

Richards, A.I. (ed.). 1960. East African Chiefs: A Study of Political Development in some Uganda and Tanganyika Tribes. New York: Praeger.

Ricklefs, Merle. 1974. Jogjakarta under Sultan Mangkubumi, 1749-1792. London: Oxford University Press.

Robinne, François and Mandy Sadan (eds). 2007. Social Dynamics in the Highlands of Southeast Asia. Leiden: Brill. 
Rutherford, Danilyn. 2002. Raiding the Land of the Foreigners. Princeton: Princeton University Press.

Sabloff, Jeremy A. (ed.). 2003. Tikal: Dynasties, Foreigners and Affairs of State. Santa Fe: School of American Research Press.

Sahlins, Marshall. 2008. 'The stranger-king: Or, elementary forms of the politics of life'. Indonesia and the Malay World 36(105): 177-99. doi. org/10.1080/13639810802267918.

——. 2004. Apologies to Thucydides: Understanding History as Culture and Vice Versa. Chicago: University of Chicago Press.

—_. 2000. Culture in Practice: Selected Essays. New York: Zone Books.

—_. 1995. How 'Natives' Think: About Captain Cook, for Example. Chicago: University of Chicago Press.

- 1994 . 'The discovery of the true savage'. In Dangerous Liaisons: Essays in Honour of Greg Dening, ed. Donna Merwick, pp. 41-94. Melbourne: History Department, University of Melbourne.

- - 1992. Historical Ethnography. Vol. 1 of Patrick V. Kirch and Marshall Sahlins, Anahulu: The Anthropology of History in the Kingdom of Hawaii. Chicago: University of Chicago Press.

—_. 1981a. 'The stranger-king; or, Dumézil among the Fijians'. Journal of Pacific History 16: 107-32. doi.org/10.1080/00223348108572419.

- 1981b. Historical Metaphors and Mythical Realities: Structure in the Early History of the Sandwich Islands Kingdom. Association for Social Anthropology in Oceania, special publication, no. 1. Ann Arbor: University of Michigan Press.

St John, Spenser. 1879. The Life of Sir James Brooke, Rajah of Sarawak. Edinburgh: Blackwood and Sons.

Sartre, Jean-Paul. 1963. Search for a Method, trans. Hazel E. Barnes. New York: Vintage Books.

Sather, Clifford. 1990. Trees and tree tenure in Paku Iban society: the management of secondary forestry resources in a long-established Iban community. Borneo Review 1: 16-40. 
Saunders, Graham. 1980. 'Seekers of kingdoms: British adventurers in the Malay archipelago'. Brunei Museum Journal 4(4): 137-54.

Schrempp, Gregory. 1992. Magical Arrows: The Maori, the Greeks and the Folklore of the Universe. Madison: University of Wisconsin Press.

Schrieke, B. 1957. Ruler and Realm in Early Java. Indonesian Sociological Studies, Part Two. The Hague: W. van Hoeve.

Schulte Nordholt, H.G. 1971. The Political System of the Atoni of Timor. The Hague: Martinus Nijhoff. doi.org/10.1007/978-94-015-1013-4.

Siikala, Jukka. 1996. 'The elder and the younger-foreign and autochthonous origin and hierarchy in the Cook Islands'. In Origins, Ancestry and Alliance: Explorations in Austronesian Ethnography, ed. James J. Fox and Clifford Sather, pp. 41-54. Canberra: Comparative Austronesian Project, Department of Anthropology, Research School of Pacific and Asian Studies, The Australian National University.

-1991. Akatokamanava: Myth, History and Society in the Southern Cook Islands. Auckland: Polynesian Society.

- 1990. 'Chiefs, gender and hierarchy in Ngaputoru'. In Culture and History in the Pacific, ed. Jukka Siikala, pp. 107-38. Helsinki: Suomen Antrpolinen Society Transactions No. 27.

Skeat, W.W. 1900. Malay Magic: An Introduction to the Folklore and Popular Religion of the Malay Peninsula. New York: Dover.

Skinner, Elliott P. 1964. The Mossi of the Upper Volta: The Political Development of a Sudanese People. Stanford: Stanford University Press.

Smith, Jean. 1974-75. 'Tapu removal in Maori religion'. Journal of the Polynesian Society (Memoirs of the Polynesian Society) 40(83): 1-43; 40(84): 44-96.

Southall, Adrian W. 2004 [1956]. Alur Society: A Study in Processes and Types of Domination. Munster: LIT with the International African Institute.

Southgate, Minoo S. (trans.). 1978. Iskandarnamah: A Persian Medieval Alexander-Romance. New York: Columbia University Press.

Sprenger, Guido. 2006. Out of Ashes: Swidden cultivation in highland Laos. Anthropology Today 22(4) August: 9-13. 
Stoneham, Richard (ed.). 1991. The Greek Alexander Romance. London: Penguin.

Strathern, Alan. 2009. 'The Vijaya origin myth of Sri Lanka and the strangeness of kingship'. Past and Present 203(1): 3-28. doi. org/10.1093/pastj/gtp019.

Stuart, David. 2000. 'The arrival of strangers: Teotihuacan and Tollan in classic Maya history'. In Mesoamerica's Classic Heritage: From Teotihuacan to the Aztecs, ed. David Carrasco, Lindsay Jones and Scott Sessions, pp. 465-514. Boulder: University of Colorado Press.

Taylor, Keith. 1999. 'The early kingdoms'. In The Cambridge History of Southeast Asia, Vol. 2, ed. Nicholas Tarling, pp. 137-82. Cambridge: Cambridge University Press.

—_. 1983. The Birth of Vietnam. Berkeley: University of California Press.

Thomas, Carol. 2007. Alexander the Great in his World. Malden, MA: Blackwell. doi.org/10.1002/9780470774236.

Took, Jennifer. 2005. A Native Chieftaincy in Southwest China: Franchising a Tai Chieftaincy under the Tusi System of Late Imperial China. Leiden: Brill.

Turton, Andrew (ed). 2000. Civility and Savagery: Social Identity in Tai States. Richmond: Curzon Press.

van Wouden, F.A.E. 1968. Types of Social Structure in Eastern Indonesia. The Hague: Martinus Nijhoff. doi.org/10.1007/978-94-015-1076-9.

Viveiros de Castro, Eduardo. 1992. From the Enemy's Point of View: Humanity and Divinity in an Amazonian Society. Chicago: University of Chicago Press.

Walker, J.H. 2002. Power and Prowess: The Origins of Brooke Kingship in Sarawak. Asian Studies Association of Australia, Allen \& Unwin. Honolulu: University of Hawai'i Press.

—_- 1998. 'James Brooke and the Bidayuh: Some ritual dimensions of dependency and resistance in nineteenth-century Sarawak'. Modern Asian Studies 32(1): 91-115. doi.org/10.1017/S0026749X98002984. 
Wang Gungwu. 1981. Community and Nation: Essays on Southeast Asia and the Chinese. Singapore: Heinemann.

Winstedt, R.O. 1938. 'The date, authorship, contents and some new Mss. of the Malay romance of Alexander the Great'. Journal of the Malayan Branch of the Royal Asiatic Society 16(2): 1-23.

Wolters, O.W. 1986. 'Restudying some Chinese writings on Sriwijaya'. Indonesia 42: 1-41. doi.org/10.2307/3351186.

— 1970. The Fall of Srivijaya in Malay History. Ithaca: Cornell University Press.

Wyatt, David K. 1984. Thailand: A Short History. New Haven: Yale University Press. 
This text is taken from Tides of Innovation in Oceania: Value, materiality and place, edited by Elisabetta Gnecchi-Ruscone and Anna Paini, published 2017 by ANU Press, The Australian National University,

Canberra, Australia. 